\title{
Immobilization and bacterial utilization of dissolved organic carbon entering the riparian zone of the alpine Enns River, Austria
}

\author{
Albert Brugger ${ }^{1}$, Bernhard Wett ${ }^{2}$, Ingrid Kolar ${ }^{1}$, Bettina Reitner ${ }^{1}$, Gerhard J. Herndl ${ }^{3, *}$ \\ ${ }^{1}$ Department of Marine Biology, Institute of Ecology and Conservation Biology, University of Vienna (IECB), Althanstr. 14, \\ PO Box 285, 1091 Vienna, Austria \\ ${ }^{2}$ Institute of Environmental Technology, University of Innsbruck, Technikerstr. 13, 6020 Innsbruck, Austria \\ ${ }^{3}$ Department of Biological Oceanography, Netherlands Institute for Sea Research (NIOZ), PO Box 59, \\ 1790 AB Den Burg, The Netherlands
}

\begin{abstract}
In order to understand the factors controlling the removal of riverine dissolved organic carbon (DOC) in the riparian zone of an alpine river, concentrations of DOC and dissolved oxygen, as well as bacterial abundance and production, were determined in interstitial waters of an experimental bank filtration site of the Enns River, Austria. Four porewater stations exhibiting differing sedimentologic and hydrologic characteristics were sampled over an annual cycle. We found that concentrations of DOC, oxygen, bacterial biomass and production decreased significantly within the first meter from the sediment-water interface. Differences in the grain size distribution among the sampling stations led to spatial heterogeneity in the permeability of the riparian sediments and in the hydraulic residence time of the infiltrating river water, resulting in specific patterns in DOC immobilization and microbial respiration. Porewater bacterial abundance and production and apparent microbial oxygen consumption were positively correlated with the hydraulic residence time of the infiltrating water. DOC occasionally accumulated in the shallow porewater layers during the winter. During the summer, DOC infiltrating from the river surface potentially explained only 36 $\pm 25 \%$ of the apparent interstitial oxygen consumption. This suggests that particulate organic carbon (POC) contributes substantially to the microbial organic carbon supply in the hyporheic zone. We conclude that the availability of POC rather than DOC infiltration determines hyporheic microbial metabolism.
\end{abstract}

KEY WORDS: Hyporheic bacteria $\cdot \mathrm{POC} \cdot \mathrm{DOC} \cdot$ Respiration $\cdot$ Sediment $\cdot$ Bank filtration $\cdot$ Enns River

Resale or republication not permitted without written consent of the publisher

\section{INTRODUCTION}

Hyporheic ecotones play a crucial role in the functioning of lotic ecosystems (Brunke \& Gonser 1997). On the one hand, hyporheic processes control the exchange of water and solutes between the rivers and streams and the adjacent groundwater and may partially determine the distribution and supply of nutrients within the lotic system (Vervier et al. 1993, Findlay \& Sobczak 1996, Valett et al. 1997). On the other

\footnotetext{
${ }^{*}$ Corresponding author. E-mail: herndl@nioz.nl
}

hand, hyporheic habitats are important storage zones for organic carbon (Leichtfried 1991, Bretschko \& Moser 1993) and are generally characterized by sharp physical and chemical gradients (Hendricks \& White 1995, Fraser \& Williams 1998), thus enabling a broad spectrum of metabolic pathways to occur within small spatial scales. As a consequence, hyporheic habitats are often hot spots in productivity and diversity of organisms (Pusch et al. 1998) and may contribute substantially to the energy flow through the lotic system (Jones \& Holmes 1996, Naegeli \& Uehlinger 1997, Romaní et al. 1998). 
Because primary production in interstitial habitats is limited to the surface layers, hyporheic heterotrophic microorganisms largely depend on the input of organic carbon and energy from allochthonous sources. Dissolved organic matter (DOM) may be imported from surface water (Findlay et al. 1993, Mann \& Wetzel 1995, Findlay \& Sobczak 1996) or groundwaters (Ford \& Naiman 1989, Fiebig \& Lock 1991, Kaplan \& Newbold 1993, Schindler \& Krabbenhoft 1998). In addition, particulate organic matter (POM) can be an important carbon source especially in shallow sediment layers (Brunke \& Gonser 1997) and might control hyporheic microbial metabolism (Hedin 1990, Sobczak et al. 1998). Overall, the extent of hydrologic interaction between surface water and groundwater and the direction of the interstitial flow (i.e. upwelling vs downwelling) are major factors controlling the availability of oxygen and nutrients and, therefore, the biological activity in hyporheic habitats (Hendricks 1993, Findlay 1995, Valett et al. 1997).

The chemical and biological characteristics of downwelling surface water change significantly upon subsurface transport (Hoehn et al. 1983, Hendricks \& White 1995, Marmonier et al. 1995). In particular, dissolved oxygen and dissolved organic carbon (DOC) have been demonstrated to decline along interstitial flow paths (Findlay et al. 1993, Hendricks 1993, Findlay \& Sobczak 1996). The removal of DOC from porewater takes place via a combination of abiotic and biotic processes (Fiebig \& Marxsen 1992) and is mainly associated with sediment biofilms (Lock et al. 1984, Freeman et al. 1995). Among biofilm organisms, heterotrophic bacteria represent a significant biomass component and may be responsible for a major part of the system's respiration (Pusch 1996). Uptake and incorporation of DOC into bacterial biomass is a key process in the potential transfer of DOC to higher trophic levels of the hyporheic food web (Meyer 1994).

The importance of subsurface zones for the processing of organic carbon and nutrients and the implication of such processes for river restoration has been recognized (e.g. Vervier et al. 1993, Brunke \& Gonser 1997). In addition, the transport of surface water through the riparian zones of rivers and lakes by artificial means (bank filtration) has become increasingly important for drinking water production, because organic matter as well as pollutants and harmful bacteria potentially present in the infiltrating water are efficiently retained during transport through the river bank (Schwarzenbach et al. 1983, Marmonier et al. 1995, Freedman et al. 1997).

Brugger et al. (in press) investigated a series of porewater and sediment stations from an experimental bank filtration site at the Enns River (Upper Austria) and found oxygen concentration, particulate organic carbon (POC) concentration, and bacterial abundance and production to decrease with increasing lateral distance from the river. The steepest gradients were observed within the first meter from the sedimentwater interface (Brugger et al. in press). Immobilization of DOC was less pronounced and mainly due to abiotic mechanisms (Kolar et al. unpubl.). These findings support earlier reports (Hoehn et al. 1983, Marmonier et al. 1995) pointing to the importance of shallow subsurface layers in modifying the quality of the infiltrating waters. In the present paper, we therefore specifically focus on the dynamics of dissolved oxygen, DOC, and bacteria in the shallow riparian porewater ( $<1 \mathrm{~m}$ from the sediment-water interface). We tested the effect of specific geohydrologic properties of the riparian surface sediments on the removal of DOC and oxygen from the infiltrating water and assessed the importance of DOC versus POC for the metabolism of the hyporheic microbial community. Furthermore, the significance of porewater bacteria versus sedimentattached bacteria was evaluated.

\section{MATERIALS AND METHODS}

Study location. The Enns River is a mesotrophic alpine river originating in the Austrian Central Alps and entering the Danube River (inset in Fig. 1). Catchment geology and hydrographic characteristics of the Enns River have been described previously (Brugger et al. in press). Sampling was carried out at an experimental bank filtration site located on the left bank of the Garsten impounding reservoir, about $10 \mathrm{~km}$ south of the town of Steyr $\left(47^{\circ} 59^{\prime} \mathrm{N}, 14^{\circ} 22^{\prime} \mathrm{E}\right)$. Infiltration of surface water into the riverbank was mediated by pumping from a water production well located about $50 \mathrm{~m}$ from the riverbank (Fig. 1). This well was put in operation on 14 October 1997. As a consequence, the direction of interstitial flow switched from a slight outflow of hyporheic groundwater (Ennskraft Inc., Dept. Technical Services, unpubl. data) to influx of river water into the riparian zone (Fig. 2, Table 1). The production rate of the well was set at $0.02 \mathrm{~m}^{3} \mathrm{~s}^{-1}$ and remained constant throughout the study period (October 1997 to September 1998).

At the study site, the aquifer material consists of a 5 to $10 \mathrm{~m}$ thick layer of calcareous glacial gravel deposits overlaying an impermeable layer of flysch (Fig. 1). Grain size analyses of the bank sediments (collected from 0 to $2 \mathrm{~m}$ depth) were performed at the beginning of the study and revealed a mean particle size distribution of $50 \%$ gravel, $35 \%$ sand, $15 \%$ silt, and $5 \%$ clay. Higher proportions of silt and clay (up to $35 \%$ ) were found near the sediment-water interface (K.-H. Steiner \& E. Mekonen unpubl. data). 
Fig. 1. Schematic cross-sectional view of the sampling site with production well, positions of the sampling points, and general geohydrologic compartments. Stns $\mathrm{C}$ and $\mathrm{F}$ were deployed in undisturbed sediments, while Stns D and E were embedded in artificially introduced filter material (grain diameter: $4 \mathrm{~mm}$ ). Symbols represent the sampling site in the river channel (O) and in the near-surface (O) and subsurface $(\boldsymbol{\Delta})$ sediment layers. For details see 'Materials and methods'. a.s.l.: above sea level

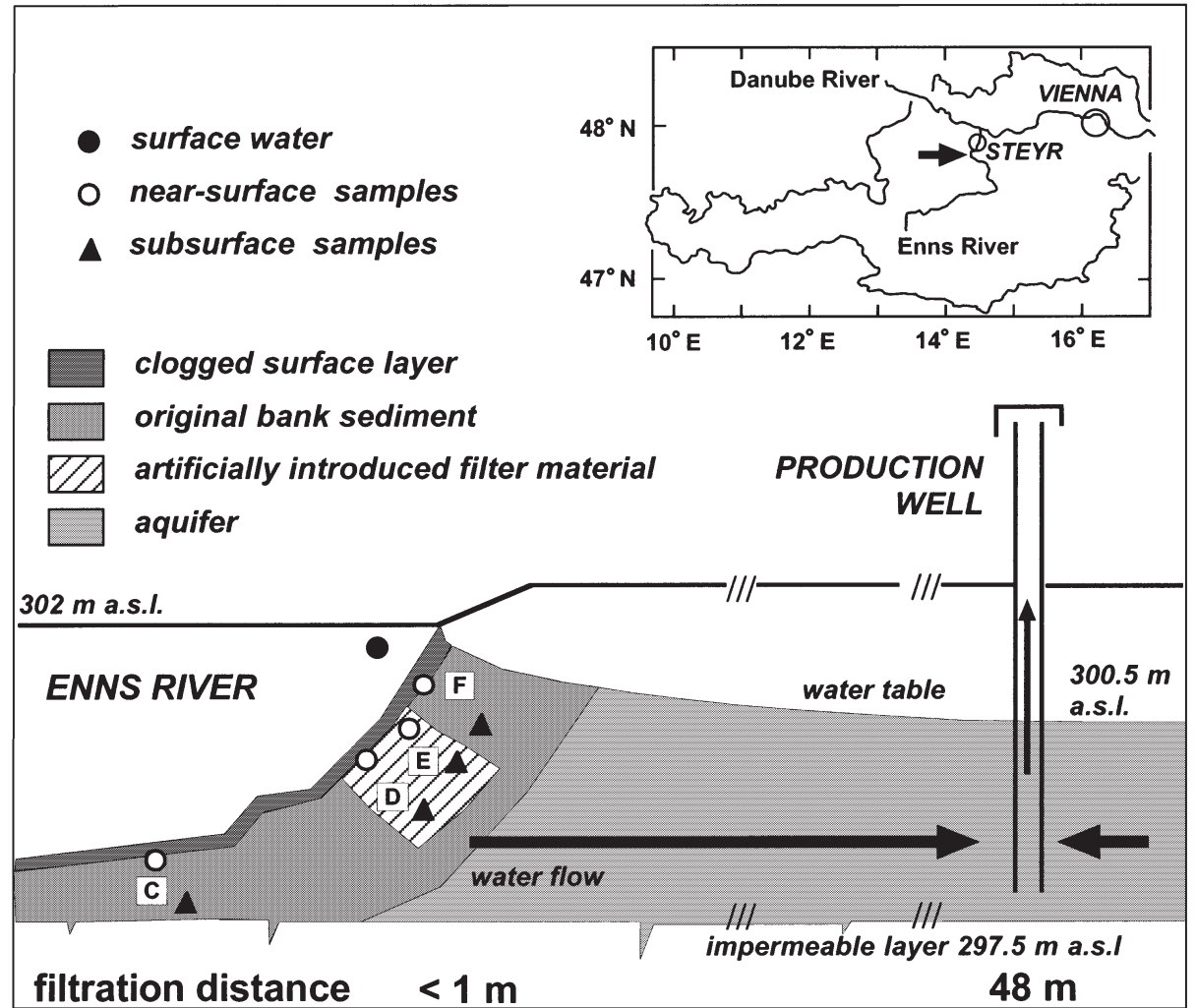

Porewater samples were taken from 4 different locations (Fig. 1): Stn C was located in the transition zone between the riverbed and the riverbank. Stn F was located on the riverbank, 0.5 to $1.5 \mathrm{~m}$ below the mean water level of the Enns River. Two additional sampling stations (Stns D and E) were also located on the riverbank, about $3 \mathrm{~m}$ downstream of Stn F, and covered a region where defined filter material had been introduced into the bank 4 mo before the beginning of this study. This defined material, consisting of calcareous gravel, was sieved and washed to obtain a mean grain diameter of $4 \mathrm{~mm}$.

Field methods. Each sampling station consisted of a pair of piezometer wells (perforated metal pipes with $10 \mathrm{~mm}$ inner diameter), which allowed one to determine the vertical hydraulic gradients (VHG) and hydraulic conductivity as well as to sample interstitial water. The positions of the individual sampling points were located at the following depths below the sediment-water interface: 0.2 and $0.9 \mathrm{~m}$ (Stn C); 0.1 and $1.0 \mathrm{~m}$ (Stn D); 0.3 and $0.9 \mathrm{~m}$ (Stn E); and 0.1 and $0.9 \mathrm{~m}$ (Stn F) (Fig. 1). For comparisons between sites, the sampling points are grouped in 'near-surface' (0.1 to $0.3 \mathrm{~m}$ ) and 'subsurface' samples ( 0.9 to $1.0 \mathrm{~m}$ from the sediment surface).

VHG were determined about once a week throughout the investigation period. VHG were defined as the difference in hydraulic head between the river channel and the interstitial water divided by the depth of the piezometer (Lee \& Cherry 1987). Negative VHG values indicate infiltration of surface water into the riparian sediments. Hydraulic conductivity ( $k f$-values) was measured at Stns D and F using falling head tests (Lohr 1969). Measurements of $k f$ were performed on 4 dates (20 October 1997, 10 November 1997, 18 May 1998, and 29 September 1998).

Temperature, concentrations of oxygen and DOC, and bacterial parameters (abundance and production) were determined at monthly intervals. Interstitial water (about $100 \mathrm{ml}$ ) was carefully withdrawn from each pipe and temperature and oxygen concentration were measured immediately using combined electrodes (WTW, Germany). Subsequently, water samples were placed into acid-rinsed and combusted $\left(450^{\circ} \mathrm{C}\right.$, $6 \mathrm{~h})$ glass vials and stored in the dark at $4^{\circ} \mathrm{C}$ until further processing (within $12 \mathrm{~h}$ ). Subsamples for bacterial abundance were preserved immediately with $2 \%$ formaldehyde (final concentration).

Measurements performed in the laboratory. DOC concentrations were measured on a Shimadzu TOC5000 analyzer (Benner \& Strom 1993). Before analysis, samples were filtered through combusted $\left(450^{\circ} \mathrm{C}, 6 \mathrm{~h}\right)$ Whatman GF/F filters. The DOC content was determined after sparging the samples with $\mathrm{CO}_{2}$-free air. 


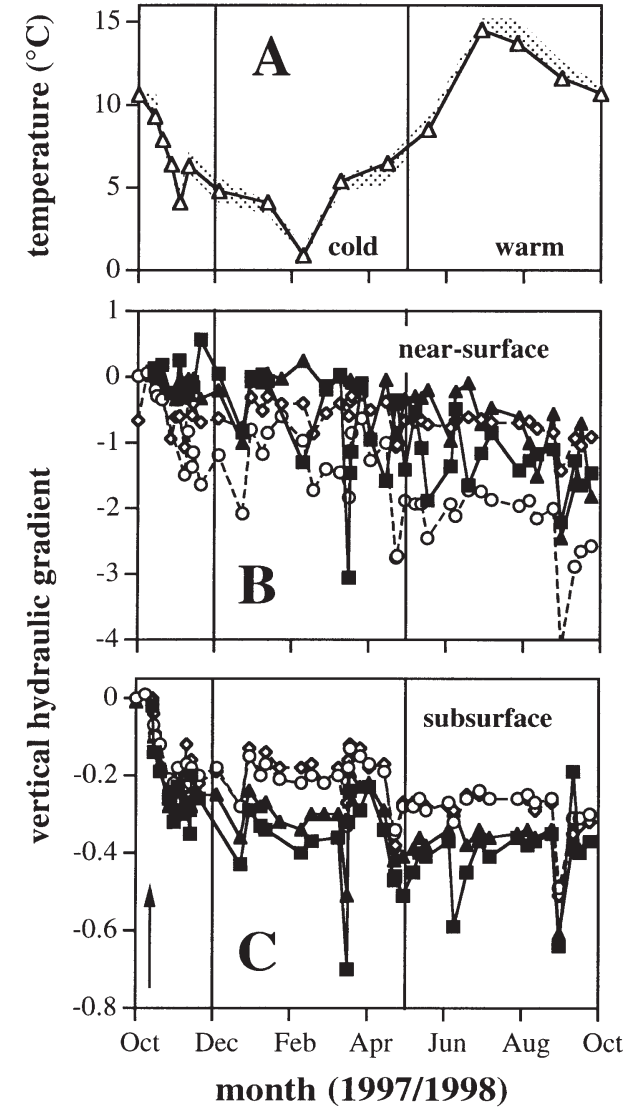

Fig. 2. (A) Seasonal variation in temperature in the surface waters of the Enns River $(\Delta)$ and at the riparian porewater stations (shaded area); (B) time course of the vertical hydraulic gradient (VHG) between the river channel and the porewater sampling points for the near-surface layer, and (C) for the subsurface layer. Symbols represent $\operatorname{Stns} C(\mathbf{\square}), \mathrm{D},(\mathbf{O}), \mathrm{E}(\diamond)$, and $F(\boldsymbol{\Delta})$. The arrow in $(C)$ refers to the beginning of pumping activity from the well on 14 October 1997

Table 1. Summary of geohydrologic characteristics from 2 stations of the investigated riverbank at Stns D and F. Hydraulic conductivity $(k f)$, filtration velocity $(v)$, and hydraulic residence time (HRT) were calculated for the shallow riparian zone (between the sediment-water interface and subsurface sediment layers; see Fig. 1)

\begin{tabular}{|lccc|}
\hline Date & $k f\left(\times 10^{-5} \mathrm{~m} \mathrm{~s}^{-1}\right)$ & $v\left(\times 10^{-5} \mathrm{~m} \mathrm{~s}^{-1}\right)$ & HRT $(\mathrm{d})$ \\
\hline Stn D & & & \\
20 Oct 1997 & 9.66 & 2.06 & 0.56 \\
10 Nov 1997 & 5.17 & 2.27 & 0.51 \\
18 May 1998 & 4.16 & 1.77 & 0.65 \\
29 Sep 1998 & 3.94 & 1.87 & 0.62 \\
Stn F & & & \\
20 Oct 1997 & 4.27 & 1.01 & 1.03 \\
10 Nov 1997 & 2.45 & 1.23 & 0.85 \\
18 May 1998 & 0.32 & 0.15 & 6.75 \\
29 Sep 1998 & 1.75 & 0.93 & 1.13 \\
\hline
\end{tabular}

Standards were prepared with potassium hydrogen biphthalate (Kanto Chemical Co Inc.). The blank was, on average, $\sim 15.2 \pm 7.7 \mu \mathrm{M} \mathrm{C}$ (range 5 to $32 \mu \mathrm{M} \mathrm{C}$ ) and the average analytical precision of the instrument was $<4 \%$. At least triplicate measurements per sample were performed.

Bacterial numbers were determined using DAPI staining and epifluorescence microscopy (Porter \& Feig 1980). At least 300 cells were enumerated per filter and sample. Bacterial production (BP) was measured via the incorporation of ${ }^{3} \mathrm{H}$-labelled leucine (specific activity: $120 \mathrm{Ci} \mathrm{mmol}^{-1}$; Amersham) into bacterial protein (Simon \& Azam 1989). Water samples were amended with $10 \mathrm{nM}$ (final concentration) leucine and incubated for $1 \mathrm{~h}$. All measurements were performed at near in situ temperature in triplicate with 1 formaldehyde-killed control. After the incubation, the samples were collected on filters and the radioactivity was determined in a scintillation counter (CanberraPackard, TriCarb 2000). Bacterial carbon production was calculated from leucine incorporation using the equations given in Simon \& Azam (1989).

Calculations. Infiltration velocities (v) were determined using Darcy's equation as $v=\mathrm{d} h / \mathrm{d} l \times k f$, where $(\mathrm{d} h / \mathrm{d} l)$ is the VHG between near-surface and subsurface sampling points and $k f$ is the average hydraulic conductivity within this layer (Lee \& Cherry 1987). The hydraulic residence time of the infiltrating water within the upper meter of the riparian zone was calculated based on a mean sediment porosity of $20 \%$ (Ingerle et al. 1999).

DOC immobilization $(\triangle \mathrm{DOC}$; sensu Fiebig \& Marxsen 1992) upon transport of river water through the top meter of the riparian zone was defined as the difference in DOC concentration between river water and the depths of the respective sediment layer. Similarly, the apparent oxygen consumption $\left(\Delta \mathrm{O}_{2}\right)$ upon filtration was calculated as the difference in oxygen concentration between river water and interstitial water collected in the respective sediment layer. $\Delta \mathrm{DOC}$ and $\Delta \mathrm{O}_{2}$ are expressed in $\mu \mathrm{mol} \mathrm{C} \mathrm{^{-1 }}$ and $\mu \mathrm{mol} \mathrm{O} \mathrm{O}_{2} \mathrm{l}^{-1}$, respectively.

In order to evaluate the role of surfacederived DOC for the metabolism of the interstitial microbial community, $\Delta \mathrm{O}_{2}$ was converted into loss of organic carbon due to microbial respiration (hyporheic carbon respiration, $\mathrm{HCR}$ ). HCR (in $\mu \mathrm{mol} \mathrm{C} \mathrm{l}^{-1}$ ) was calculated as $\Delta \mathrm{O}_{2} \times 0.85 ; 0.85$ was used as the respiratory quotient (Fischer et al. 1996 and references therein).

Statistical analyses. Differences between sample means were tested for significance using analysis of variance (ANOVA), if con- 
ditions for parametric methods were met; otherwise, Friedman's test was used. Grouping variables were: station (Stns C, D, E and F), sediment depth ('near-surface', 'subsurface') and season ('cold', i.e. December 1997 to April 1998; 'warm', i.e. May to September 1998). Post-hoc comparisons were performed using Scheffe's test (SAS Institute Inc. 1998). Respective losses of DOC and oxygen were compared using Student's $t$-tests. Relationships between the parameters were examined using Pearson's correlation coefficient. Multiple regression models were applied to predict losses of DOC and oxygen during filtration.

All statistical analyses were performed using the SAS StatView 5.0 software. Log-transformation was used to normalize data. Homogeneity of variance among sample means was confirmed using Bartlett's test (SAS Institute Inc. 1998).

\section{RESULTS}

\section{Temperature regime}

In the river, water temperature showed a marked seasonality ranging between $0.9^{\circ} \mathrm{C}$ (9 February 1998) and $14.5^{\circ} \mathrm{C}$ (29 June 1998; Fig. 2A). The temperature of the porewater strongly followed the seasonal pattern observed in the river channel ( $\mathrm{r}$ always $>0.95$; $\mathrm{n}=23 ; \mathrm{p}<0.001$ ), with similar interstitial tempera- tures at all stations and sediment layers. Consequently, no significant differences in temperature between stations or depth layers were detectable (2-way ANOVA; p > 0.05).

\section{Vertical hydraulic gradient and hydraulic conductivity}

The seasonal patterns of the VHG between the river channel and the porewater stations (Fig. 2B,C) illustrate the shift in the direction of the interstitial flow at the beginning of the investigation period. As pumping was started (on 14 October 1997), VHG generally turned from slightly positive values to negative values. Especially in the near-surface sediment $(0.1$ to $0.3 \mathrm{~m}$ depth; Fig. 2B), VHG was affected by fluctuations of the river water table elevation ( $\mathrm{r}$ always $>0.70$; $\mathrm{n}=42$; $\mathrm{p}<0.001$ ). Despite these short-term fluctuations, however, VHG steadily increased at all stations over the investigation period (indicated by more negative values). VHG was much steeper in near-surface sediment layers (Fig. 2B) than in the subsurface layers and was most pronounced at Stn D (Fig. 2C). In the subsurface layers, VHG was significantly higher at stations with natural filter material than at stations with artificially introduced filter material (Fig. 2C, Table 2). During the warm season, VHG was most pronounced at Stn C (Table 2).

Table 2. Friedman-test on differences between stations (Stns C, D, E and F) in vertical hydraulic gradient (VHG), concentrations of DOC and oxygen, and bacterial parameters (abundance [BA] and production [BP]). Data were log-transformed before analysis and grouped according to depth layer and season; see 'Materials and methods' section). $\mathrm{df}=3$; - : not determined (due to missing values); $\Leftrightarrow$ denotes significant differences between stations in post-hoc comparison (using Scheffé's repeated measures design; $\alpha=0.05$ )

\begin{tabular}{|c|c|c|c|c|c|c|}
\hline Parameter & Depth layer & Season & $\mathrm{n}$ & $\chi^{2}$ & $\mathrm{p}$ & Post-hoc groups \\
\hline \multirow[t]{4}{*}{ VHG } & \multirow[t]{2}{*}{ Near-surface } & Cold & 26 & 45.554 & $<0.001$ & $\mathrm{D} \Leftrightarrow \mathrm{CEF}$ \\
\hline & & Warm & 16 & 34.425 & $<0.001$ & $\mathrm{D} \Leftrightarrow \mathrm{CEF}$ \\
\hline & \multirow[t]{2}{*}{ Subsurface } & Cold & 26 & 53.765 & $<0.001$ & $\mathrm{CF} \Leftrightarrow \mathrm{DE}$ \\
\hline & & Warm & 16 & 35.175 & $<0.001$ & $\mathrm{C} \Leftrightarrow \mathrm{DE} \Leftrightarrow \mathrm{F}$ \\
\hline \multirow[t]{4}{*}{ DOC } & \multirow[t]{2}{*}{ Near-surface } & Cold & 5 & 7.980 & 0.046 & $\mathrm{C} \Leftrightarrow \mathrm{DEF}$ \\
\hline & & Warm & 5 & 1.140 & 0.767 & \\
\hline & \multirow[t]{2}{*}{ Subsurface } & Cold & 5 & 5.040 & 0.169 & \\
\hline & & Warm & 5 & 10.260 & 0.017 & $\mathrm{C} \Leftrightarrow \mathrm{DEF}$ \\
\hline \multirow[t]{4}{*}{ Oxygen } & \multirow[t]{2}{*}{ Near-surface } & Cold & 5 & 9.780 & 0.021 & $\mathrm{C} \Leftrightarrow \mathrm{DEF}$ \\
\hline & & Warm & 5 & 8.280 & 0.041 & $\mathrm{C} \Leftrightarrow \mathrm{E}$ \\
\hline & \multirow{2}{*}{ Subsurface } & Cold & 5 & 14.460 & 0.002 & $\mathrm{C} \Leftrightarrow \mathrm{DE}$ \\
\hline & & Warm & 5 & 12.064 & 0.007 & $\mathrm{C} \Leftrightarrow \mathrm{DF} \Leftrightarrow \mathrm{E}$ \\
\hline \multirow[t]{4}{*}{$\mathrm{BA}$} & \multirow[t]{2}{*}{ Near-surface } & Cold & 5 & 13.560 & 0.004 & $\mathrm{CF} \Leftrightarrow \mathrm{DE}$ \\
\hline & & Warm & 3 & - & - & $\mathrm{C} \Leftrightarrow \mathrm{DE} \Leftrightarrow \mathrm{F}$ \\
\hline & \multirow[t]{2}{*}{ Subsurface } & Cold & 5 & 4.920 & 0.178 & \\
\hline & & Warm & 5 & 4.938 & 0.286 & \\
\hline \multirow[t]{4}{*}{$\mathrm{BP}$} & \multirow[t]{2}{*}{ Near-surface } & Cold & 5 & 8.760 & 0.033 & $\mathrm{CF} \Leftrightarrow \mathrm{DE}$ \\
\hline & & Warm & 5 & 12.120 & 0.007 & $\mathrm{CF} \Leftrightarrow \mathrm{DE}$ \\
\hline & \multirow[t]{2}{*}{ Subsurface } & Cold & 5 & 11.880 & 0.008 & $\mathrm{C} \Leftrightarrow \mathrm{DEF}$ \\
\hline & & Warm & 5 & 10.860 & 0.012 & $\mathrm{C} \Leftrightarrow \mathrm{DEF}$ \\
\hline
\end{tabular}


The $k f$-values obtained for Stns D and F (Table 1) provide an explanation for the observed patterns in VHG (shown in Fig. 2). Hydraulic conductivity was significantly lower at Stn F than at Stn D (paired $t$-test; $\mathrm{p}<0.05$ ), presumably caused by the higher proportion of fine particles present at the undisturbed sites than at sites with artificially introduced filter material. Infiltration velocity at Stn D was always at least twice as high as at Stn F (Table 1).

\section{Dynamics of DOC and dissolved oxygen in the riparian porewater}

Due to the pumping activity, hyporheic porewater was replaced by water infiltrating from the river. This resulted in considerable changes in porewater chemistry within 1 mo (from October to November 1997) after pumping from the well had started, which also affected the distribution of organic carbon and the microbial metabolism within the shallow hyporheic zone. In the following we focus on the dynamics of DOC and dissolved oxygen between December 1997 and September 1998, when river water predominated at all sampling sites (Brugger et al. in press).

The concentration of river DOC remained relatively stable over the investigation period (mean \pm SD: $89 \pm$

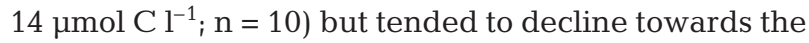

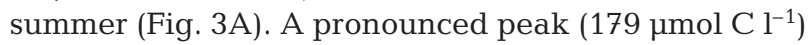
was detected on 27 July 1998, coinciding with enhanced precipitation prior to the sampling date. The porewater DOC concentrations followed the seasonal pattern observed in the river channel but were generally lower than the corresponding river values. At Stns D, E, and F, decreases in DOC concentration were detectable mainly between the sediment-water interface and the near-surface layers (paired $t$-test; $\mathrm{p}<$ 0.01). No significant further DOC decline was detectable between the near-surface and subsurface sediment layers except for Stn C, where DOC concentrations significantly declined between these layers (paired $t$-test; $\mathrm{p}<0.01$ ). The overall DOC loss within the top meter of filtration was therefore higher at Stn C $(33 \pm 10 \%$ of the river DOC concentration; $\mathrm{n}=10)$ than at the other stations $(15 \pm 13 \%, \mathrm{n}=10$; Fig. $3 \mathrm{~A})$.

In the river water, oxygen concentrations were highest in Febrary (411 $\mu_{\mathrm{mol} \mathrm{O}} \mathrm{O}^{-1}$ ) and decreased afterwards until the end of the study (Fig. 3B). The lowest oxygen concentration was measured in August $\left(295 \mu \mathrm{mol} \mathrm{O} \mathrm{I}^{-1}\right)$. Oxygen saturation in the river averaged $93 \pm 5 \%(n=10)$ over the investigation period, with no significant difference detectable between seasons (ANOVA; $\mathrm{p}>0.05)$. During the winter, interstitial oxygen concentration declined only slightly with depth, especially at locations with artificially intro- duced gravel (Stns D and E). Oxygen concentration decreased only by $5 \pm 3 \%$ at Stn D and by $3 \pm 2 \%$ at Stn E over the first meter of filtration. Significantly steeper $\mathrm{O}_{2}$ gradients were observed at Stn C (22 \pm $10 \%)$ and at Stn F (13 $\pm 10 \%$; Table 2). During the summer, oxygen concentration generally declined more rapidly with depth (Fig. 3B). Again, oxygen decline was highest at Stns C $(42 \pm 11 \%$ the respective river values) and F $(39 \pm 13 \%)$, followed by Stns D $(29 \pm$ $10 \%)$ and $\mathrm{E}(14 \pm 7 \%)$.

\section{Interstitial bacterial abundance and production}

Riverine bacterial abundance displayed a pronounced seasonal dynamic, with lowest numbers $\left(\approx 5 \times 10^{8}\right.$ cells $\mathrm{l}^{-1}$ ) from Febrary through April 1998 and highest numbers $\left(16 \times 10^{8}\right.$ cells $\left.1^{-1}\right)$ in June and July 1998 (Fig. 3C). Site-specific differences in bacterial abundance were discernible for the near-surface layer (Table 2). At locations with artificially introduced gravel (Stns D and E), bacterial abundance declined sharply with depth (paired $t$-test; $\mathrm{p}<0.001$ ) to about $30 \%$ of the corresponding river values, with only minor seasonal variation $\left(2 \pm 1 \times 10^{8}\right.$ cells $\left.\mathrm{l}^{-1}\right)$. In contrast, the near-surface sediment layers of Stns $C$ and $F$ showed much higher seasonal variations, following the pattern observed in the river channel (Fig. 3C). Both stations showed similar bacterial numbers $\left(6 \pm 2 \times 10^{8}\right.$ cells $\left.^{-1}\right)$ during the cold season, whereas, during the summer, bacterial abundance was significantly higher at Stn C $\left(13 \pm 3 \times 10^{8}\right.$ cells $\left.^{-1}\right)$ than at Stn F $\left(6 \pm 3 \times 10^{8}\right.$ cells $^{-1}$; Table 2). In the subsurface layer (at 0.9 to $1 \mathrm{~m}$ distance from the river water-sediment interface), porewater bacterial abundance was significantly lower than in the river channel (paired $t$-test; $\mathrm{p}<0.001$ ) and averaged $1.7 \pm 0.9 \times 10^{8}$ cells $\mathrm{l}^{-1}$, with no significant differences discernible among stations (Table 2).

Porewater bacterial production followed a seasonal pattern that differed considerably from that observed for the river (Fig. 3D). Significant differences were also observed between locations with natural filter material and artificially introduced filter material (Table 2). At Stns D and E (with artificially introduced gravel), bacterial production was generally lower than in the river, with no significant differences detectable between the 2 stations and the 2 depth layers (2-way ANOVA; $\mathrm{p}>$ 0.05). In contrast, at Stns $C$ and F, near-surface bacterial production was significantly (up to 20 times) higher (paired $t$-test; $\mathrm{p}<0.01$ ) than in the river, with maximum production rates measured in January $(0.8$ to

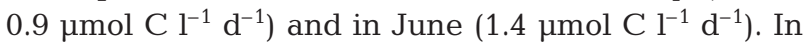
the subsurface layer, Stn C displayed significantly higher bacterial production rates than any other location (Table 2). 


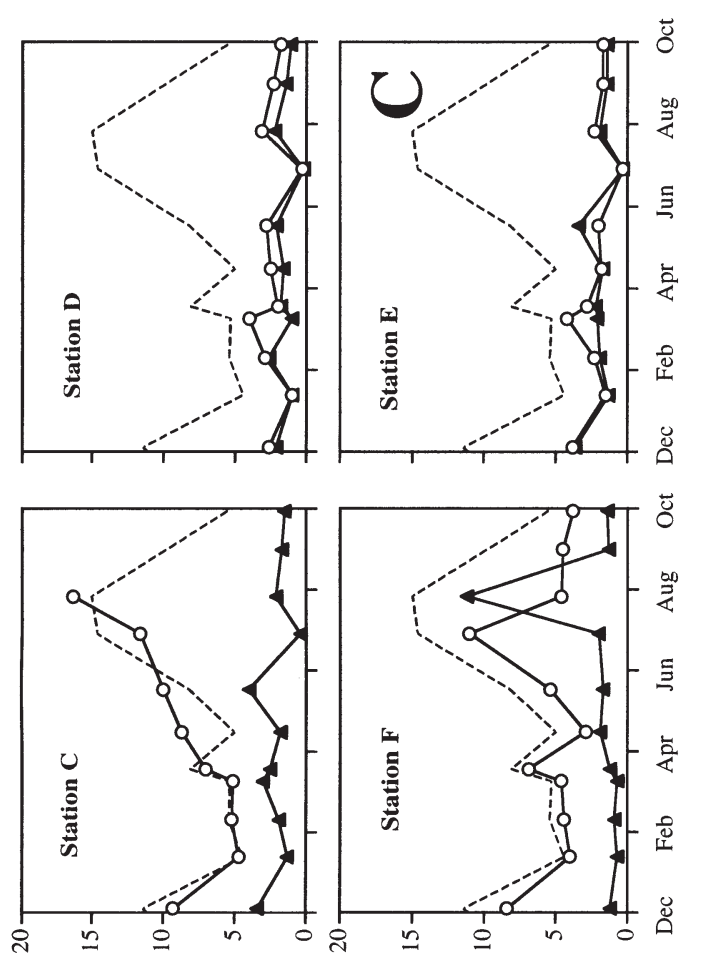

bacterial abundance $\left(10^{8}\right.$ cells $\left.\mathrm{I}^{-1}\right)$
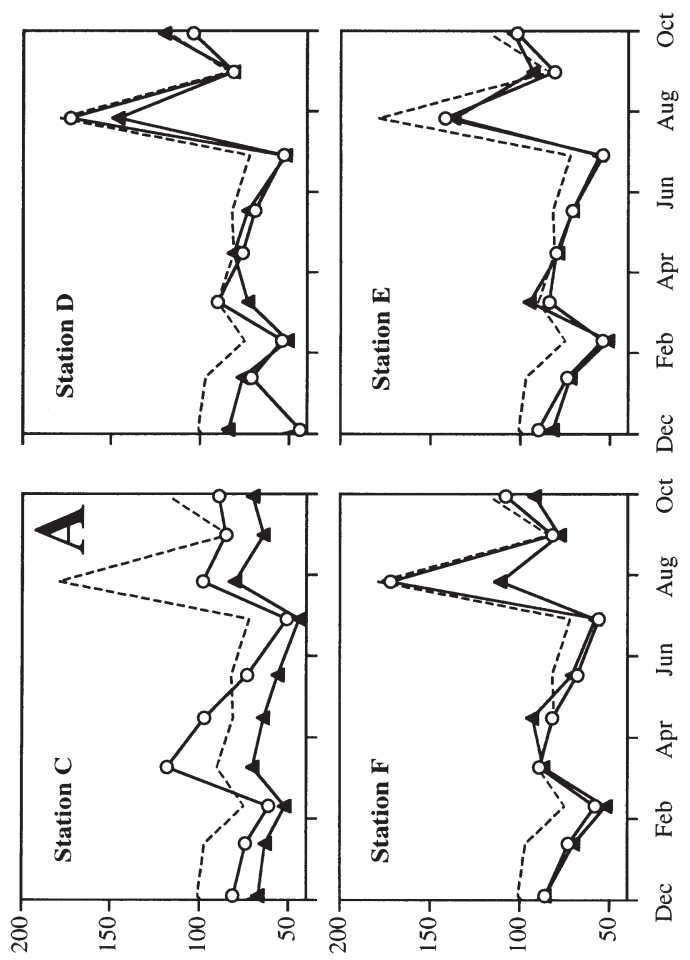

DOC concentration $\left(\mu \mathrm{mol} \mathrm{Cl}^{-1}\right)$

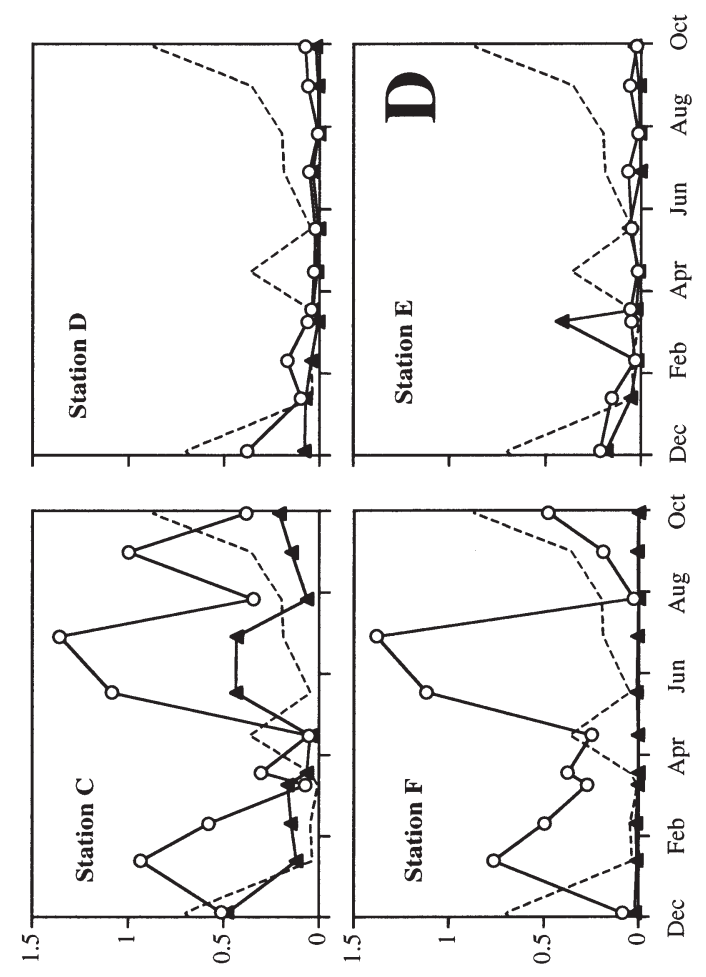

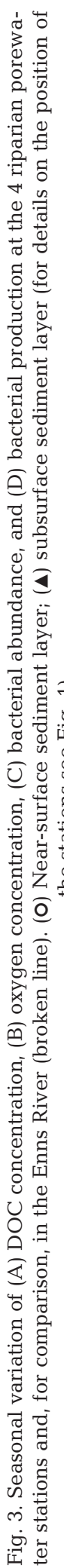


Table 3. Pearson's correlation coefficients between temperature, vertical hydraulic gradient (VHG), concentrations of DOC and oxygen, and bacterial abundance (BA) and production (BP) in the riparian porewater; $\mathrm{n}=80$ (BA: $\mathrm{n}=78$ ). Levels of significance: ${ }^{*} \mathrm{p}<0.05 ;{ }^{* *} \mathrm{p}<0.01 ;{ }^{* * *} \mathrm{p}<0.001$

\begin{tabular}{|lccccc|}
\hline & Temperature & VHG & DOC conc. & Oxygen conc. & BA \\
\hline VHG & $-0.303^{* *}$ & & & & \\
DOC conc. & $0.333^{* *}$ & -0.111 & & & \\
Oxygen conc. & $-0.798^{* * *}$ & 0.218 & $-0.258^{*}$ & -0.082 & \\
BA & 0.070 & -0.143 & -0.138 & -0.003 & $0.593^{* * *}$ \\
BP & 0.048 & -0.094 & $-0.248^{*}$ & -0.3 \\
\hline
\end{tabular}

\section{Interaction between bacterial abundance and production and physical and chemical parameters}

Bacterial variables were only weakly related to the measured physical and chemical parameters. When data from all stations and depth layers were pooled, neither temperature, VHG, or concentrations of DOC and oxygen correlated with bacterial abundance (Table 3), and only DOC concentration correlated weakly with bacterial production $(\mathrm{r}=-0.248$; $\mathrm{p}<0.05$; Table 3). However, bacterial abundance was significantly correlated with temperature $(\mathrm{r}=0.878 ; \mathrm{p}<0.01)$ and oxygen concentration $(r=-0.892 ; p<0.01)$ in the near-surface layer of Stn C. Similarly, a relationship between bacterial production and DOC concentration was obtained $(r>0.600 ; \mathrm{p}<0.05)$ if only data from the near-surface layers were considered. Pooling all the stations and depth layers, bacterial abundance was significantly correlated with production $(\mathrm{r}=0.593$; $\mathrm{p}<0.001$; Table 3).

\section{DOC immobilization and hyporheic carbon respira- tion in the riparian zone}

Over the first 0.9 to $1 \mathrm{~m}$ of water transport, DOC immobilization $(\triangle \mathrm{DOC} ;$ Fig. 4) varied irregularly between seasons (ANOVA; $\mathrm{p}>0.05)$, but was signifi-

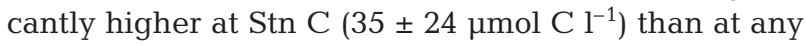

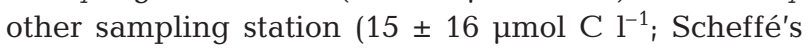
post-hoc comparison; $\mathrm{p}<0.05)$. The decline in DOC over the top meter layer was highest in July, coinciding with highest DOC concentrations in the river (Fig. 3A). Hyporheic carbon respiration ( $\mathrm{HCR}_{i}$ calculated from the apparent oxygen consumption) was low from December through February and increased with increasing temperature towards the summer (Fig. 4). HCR was highest at Stns $C$ and F (overall mean \pm SD:

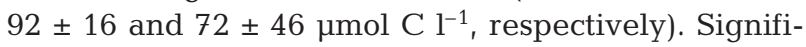
cant differences were detected also between Stns D

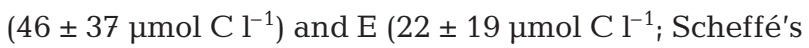
post-hoc test).

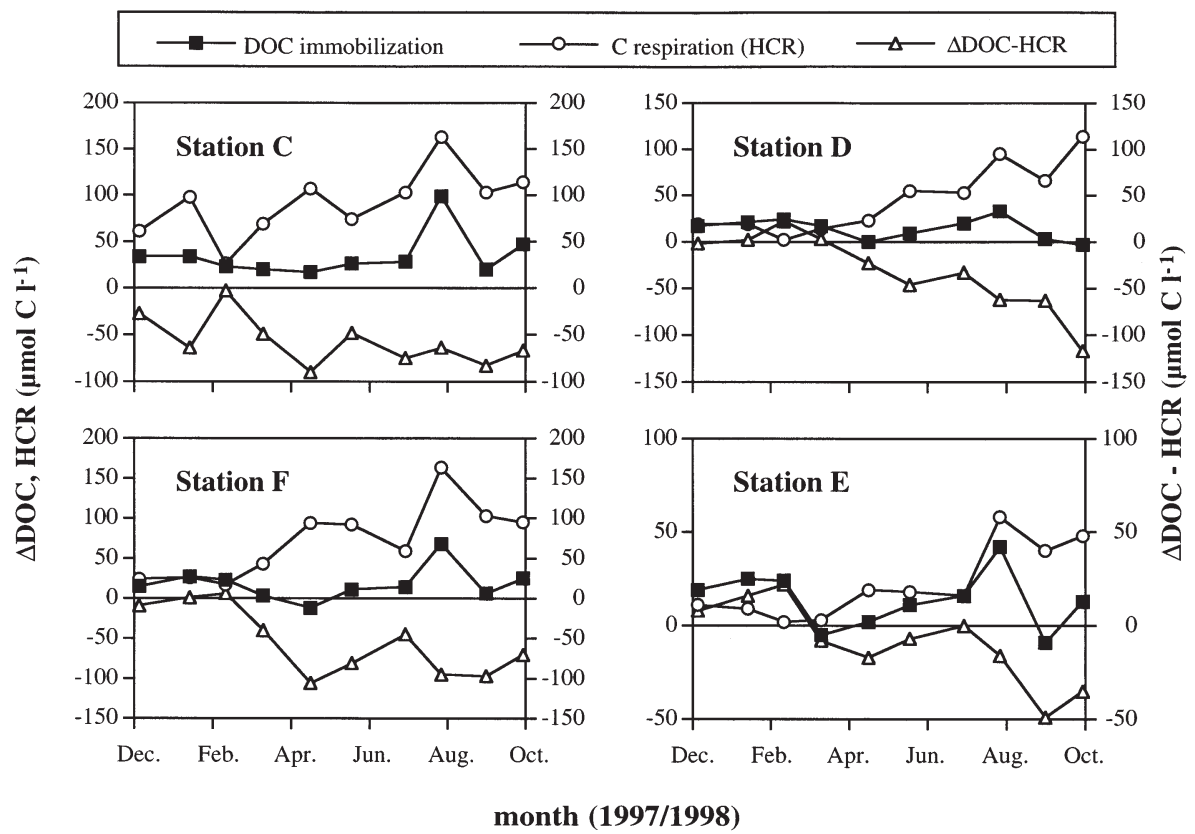

Fig. 4. Seasonal variation of DOC immobilization $(\triangle \mathrm{DOC})$, total hyporheic carbon respiration (HCR), and the difference between $\triangle \mathrm{DOC}$ and HCR $(\triangle \mathrm{DOC}-$ $\mathrm{HCR}$ ) in the riparian zone (within 0.9 to $1 \mathrm{~m}$ from the sediment-water interface). Note different scales on $y$-axes 
Higher $\triangle \mathrm{DOC}$ than $\mathrm{HCR}$ values in Fig. 4 indicate accumulation of DOC within the sediment, while $\triangle \mathrm{DOC}<\mathrm{HCR}$ indicates the amount of organic carbon respired which cannot be explained by the observed loss of DOC. The magnitude of the imbalance between $\triangle \mathrm{DOC}$ and HCR varied significantly between stations and seasons (2-way ANOVA; $\mathrm{p}<0.05$ and $\mathrm{p}<0.001$, respectively). At Stn $\mathrm{C}, \mathrm{HCR}$ was always higher than $\Delta$ DOC (paired $t$-test; $\mathrm{p}<0.001$ ). Microbial DOC mineralization could account for, at most, $45 \pm 26 \%$ of the apparent oxygen consumption, assuming that no abiotic loss of DOC from the porewater took place. The stations located farther along the riverbank were characterized by occasional accumulation of DOC during the winter (especially at Stns D and E, where $\triangle \mathrm{DOC}$ was significantly higher than $\mathrm{HCR}_{\text {; }}$ paired $t$-test; $\left.\mathrm{p}<0.05\right)$. From March through September 1998, HCR clearly exceeded $\Delta \mathrm{DOC}$ at all sampling sites (paired $t$-test; $\mathrm{p}<0.001$ ). During this period, DOC removal from porewater explained $36 \pm 25 \%$ of the concurrent oxygen consumption (Fig. 4).

\section{Effects of temperature, VHG, and river DOC concentration on DOC immobilization and apparent oxygen consumption in the riparian zone}

DOC removal from infiltrating water $(\triangle \mathrm{DOC})$ appeared to be largely unaffected by porewater temperature or VHG, although VHG and $\triangle \mathrm{DOC}$ correlated at Stn $\mathrm{D}(\mathrm{r}=-0.793 ; \mathrm{p}<0.05$; Table 4$)$. The relation between $\triangle \mathrm{DOC}$ and river DOC concentrations (Fig. 3A) was highly site-dependent. While the DOC concentration of the river channel was strongly related to $\triangle \mathrm{DOC}$ at $\operatorname{Stn} C(r=0.903 ; p<0.001)$, DOC immobilization was not related to DOC concentrations at the other locations (Table 4). Consequently, temperature, VHG, and river DOC concentration are poor predictors for $\triangle \mathrm{DOC}$, except at Stns C and D, where 83 and $74 \%$, respectively, of the variance in $\triangle \mathrm{DOC}$ could be explained by temperature, VHG, and river DOC concentration (Table 5).

Hyporheic oxygen consumption was mainly related to porewater temperature ( $\mathrm{r}$ always $>0.84 ; \mathrm{p}<0.01$ ).

Table 4. Interaction of temperature, vertical hydraulic gradient (VHG), and DOC concentration in the infiltrating river water with DOC immobilization $(\triangle \mathrm{DOC})$ and oxygen consumption $\left(\Delta \mathrm{O}_{2}\right)$ within the upper meter of the riparian zone. Pearson's correlation coefficients (of log-transformed data) are given for single stations and for pooled data from all stations. Levels of significance as in Table 3

\begin{tabular}{|c|c|c|c|c|c|}
\hline \multirow[t]{2}{*}{ Correlation } & \multicolumn{5}{|c|}{ Correlation coefficient (r) } \\
\hline & Stn C & Stn D & Stn E & Stn F & All stations \\
\hline Temperature $\times \Delta \mathrm{DOC}$ & 0.389 & -0.297 & -0.115 & -0.020 & -0.019 \\
\hline $\mathrm{VHG} \times \triangle \mathrm{DOC}$ & -0.274 & $-0.793^{*}$ & 0.115 & -0.226 & -0.010 \\
\hline River DOC conc. $\times \triangle \mathrm{DOC}$ & $0.903^{* * *}$ & 0.393 & 0.466 & 0.612 & $0.512^{* *}$ \\
\hline Temperature $\times \Delta \mathrm{O}_{2}$ & $0.863^{* *}$ & $0.959^{* * *}$ & $0.840^{* *}$ & $0.837^{* *}$ & $0.701^{* * *}$ \\
\hline $\mathrm{VHG} \times \Delta \mathrm{O}_{2}$ & 0.070 & 0.520 & $0.651^{*}$ & 0.523 & $0.674^{* * *}$ \\
\hline$\Delta \mathrm{DOC} \times \Delta \mathrm{O}_{2}$ & 0.466 & -0.322 & -0.094 & 0.119 & $0.148^{*}$ \\
\hline Counts & 10 & 10 & 10 & 10 & 40 \\
\hline
\end{tabular}

Table 5. Results of multiple regression analyses to predict DOC immobilization ( $\triangle D O C)$ upon filtration of river water through the riparian zone ( 0 to $1 \mathrm{~m})$. Independent variables $\left(x_{i}\right)$ were entered in successive models. Standardized partial regression coefficients $(\beta-$ coeff.; with level of significance of the associated $t$-value) are given for each independent variable. Levels of significance as in Table 3

\begin{tabular}{|c|c|c|c|c|c|}
\hline $\begin{array}{l}\text { Stn } \\
\text { (n) }\end{array}$ & River DOC conc. & $\begin{array}{c}\text { oeff. }\left(x_{\mathrm{i}}\right) \\
\text { VHG }\end{array}$ & $\overline{\text { Temperature }}$ & Model $\mathrm{R}^{2}$ & $\mathrm{p}$ \\
\hline $\mathrm{C}$ & $0.903^{* * *}$ & & & 0.82 & $<0.001$ \\
\hline \multirow[t]{2}{*}{ (10) } & $0.887^{* * *}$ & -0.068 & & 0.82 & 0.003 \\
\hline & $0.850^{*}$ & -0.091 & 0.083 & 0.83 & 0.011 \\
\hline D & 0.393 & & & 0.15 & 0.336 \\
\hline \multirow[t]{2}{*}{ (10) } & 0.327 & $-0.765^{*}$ & & 0.73 & 0.036 \\
\hline & 0.351 & -0.731 & -0.068 & 0.74 & 0.117 \\
\hline E & 0.466 & & & 0.22 & 0.244 \\
\hline \multirow[t]{2}{*}{ (10) } & 0.476 & -0.032 & & 0.22 & 0.540 \\
\hline & 0.587 & 0.267 & -0.518 & 0.36 & 0.571 \\
\hline $\mathrm{F}$ & 0.612 & & & 0.37 & 0.080 \\
\hline \multirow[t]{2}{*}{ (10) } & 0.593 & -0.152 & & 0.38 & 0.219 \\
\hline & 0.693 & -0.041 & -0.247 & 0.44 & 0.371 \\
\hline All stations & $0.512^{* *}$ & & & 0.26 & 0.002 \\
\hline \multirow[t]{2}{*}{$(40)$} & $0.512^{* *}$ & 0.003 & & 0.26 & 0.008 \\
\hline & $0.615^{* * *}$ & 0.109 & -0.281 & 0.32 & 0.007 \\
\hline
\end{tabular}


Table 6. Results of multiple regression analyses to predict oxygen consumption $\left(\Delta \mathrm{O}_{2}\right)$ upon filtration of river water through the riparian zone ( 0 to $1 \mathrm{~m}$ ). Regression parameters and levels of significance as in Table 5

\begin{tabular}{|c|c|c|c|c|c|}
\hline $\begin{array}{l}\text { Stn } \\
\text { (n) }\end{array}$ & Temperature & $\begin{array}{c}\text { oeff. }\left(x_{\mathrm{i}}\right) \\
\text { VHG }\end{array}$ & $\Delta \mathrm{DOC}$ & model $\mathrm{R}^{2}$ & $\mathrm{p}$ \\
\hline $\mathrm{C}$ & $0.863^{* *}$ & & & 0.75 & 0.001 \\
\hline \multirow[t]{2}{*}{ (10) } & $0.878^{* *}$ & -0.086 & & 0.75 & 0.008 \\
\hline & $0.815^{*}$ & -0.036 & 0.139 & 0.77 & 0.026 \\
\hline D & $0.959^{* * *}$ & & & 0.95 & $<0.001$ \\
\hline \multirow{2}{*}{ (10) } & $0.920^{* * *}$ & 0.083 & & 0.93 & $<0.001$ \\
\hline & $0.958^{* *}$ & 0.026 & -0.016 & 0.95 & 0.004 \\
\hline $\mathrm{E}$ & $0.840^{* *}$ & & & 0.71 & 0.002 \\
\hline \multirow[t]{2}{*}{ (10) } & $0.706^{*}$ & 0.22 & & 0.74 & 0.010 \\
\hline & $0.870^{*}$ & 0.073 & -0.003 & 0.85 & 0.043 \\
\hline $\mathrm{F}$ & $0.837^{* *}$ & & & 0.70 & 0.003 \\
\hline \multirow[t]{2}{*}{ (10) } & $0.747^{* *}$ & 0.229 & & 0.75 & 0.008 \\
\hline & $0.723^{* *}$ & 0.366 & 0.216 & 0.87 & 0.011 \\
\hline All stations & $0.701^{* * *}$ & & & 0.49 & $<0.001$ \\
\hline \multirow[t]{2}{*}{$(40)$} & $0.520^{* * *}$ & $0.476^{* * *}$ & & 0.69 & $<0.001$ \\
\hline & $0.569^{* * *}$ & $0.481^{* * *}$ & 0.164 & 0.78 & $<0.001$ \\
\hline
\end{tabular}

Interactions with other potentially important variables (VHG, $\triangle \mathrm{DOC}$ ) were less pronounced and generally not significant (Table 4). Temperature was a good predictor for interstitial oxygen consumption, explaining at least $70 \%$ of the variance in $\Delta \mathrm{O}_{2}$ (Table 6). Including VHG as an additional independent variable in multiple regression analysis led only to a slight increase of the model $\mathrm{R}^{2}$ whereas $\triangle \mathrm{DOC}$ as the third independent variable improved the model for Stns $E$ and $F\left(R^{2}=0.85\right.$ and 0.87 , respectively).

Pooling apparent oxygen consumption data from all the stations, we found that apparent oxygen consumption was related to temperature and VHG (Fig. 5A, B), whereas no relation between $\triangle \mathrm{DOC}$ and $\Delta \mathrm{O}_{2}$ was observed (Fig. 5C). However, linear regression of apparent oxygen consumption versus temperature yielded a much lower $\mathrm{R}^{2}$ for pooled data $\left(\mathrm{R}^{2}=0.49\right)$ than for data from the individual stations (Table 6). As is evident from Fig. 5A, higher residual variance in the pooled $\Delta \mathrm{O}_{2}$ data resulted from significant differences in oxygen consumption between locations where natural sediment was present and those with artificially introduced filter material (Scheffé's test; $p<0.05$ ). By including VHG as a predictor in multiple regression analysis, we found a significant improvement in model quality $\left(\mathrm{R}^{2}=0.69\right.$; Table 6$)$. Altogether, temperature, VHG, and DOC immobilization explained $78 \%$ of the variance of the hyporheic apparent oxygen consumption (Table 6).

\section{DISCUSSION}

The sampling stations differed considerably from each other with respect to their hydraulic, geochemical, and biological characteristics (Figs. 2 to 4), particularly during the warm season (Table 2), possibly because low winter temperatures (Fig. 2A) limited the overall metabolic activity of the interstitial microorganisms.

\section{Geohydrologic conditions}

Hydraulic conductivity is generally higher in wellsorted sediments than in heterogeneous, poorly sorted sediments (e.g. Beyer 1964). Consistent with this, the $k f$-values obtained in this study indicate a higher permeability of the defined, artificially introduced filter material as compared to the original bank sediment (Table 1). Similarly, the VHG between the river channel and the subsurface depth layer was steeper at the stations with original sediment than at those within the artificially introduced gravel (Fig. 2C). In the near-surface layer, VHG varied over a wider range among the different stations than in the subsurface layer and was highest at Stn D (Fig. 2B). Generally, our VHG and $k f$-values indicate that deposition of fine suspended material (riverbed clogging) mainly occurred within the top sediment layer (i.e. within $10 \mathrm{~cm}$ from the sediment-water interface).

The temporal patterns of VHG and hydraulic conductivity indicate a general decline in the permeability of the bank sediments from October 1997 through April 1998 (Fig. 2, Table 1). Thereafter, VHG remained relatively constant throughout the warm season (May to September 1998), implying that the clogging of the sediment surface had reached a stable level, although small-scale spatial variations in hydraulic conductivity resulted in a considerable range of filtration velocity at Stn F (Table 1). The stations with artificially introduced gravel (Stns D and E) were apparently less affected by 

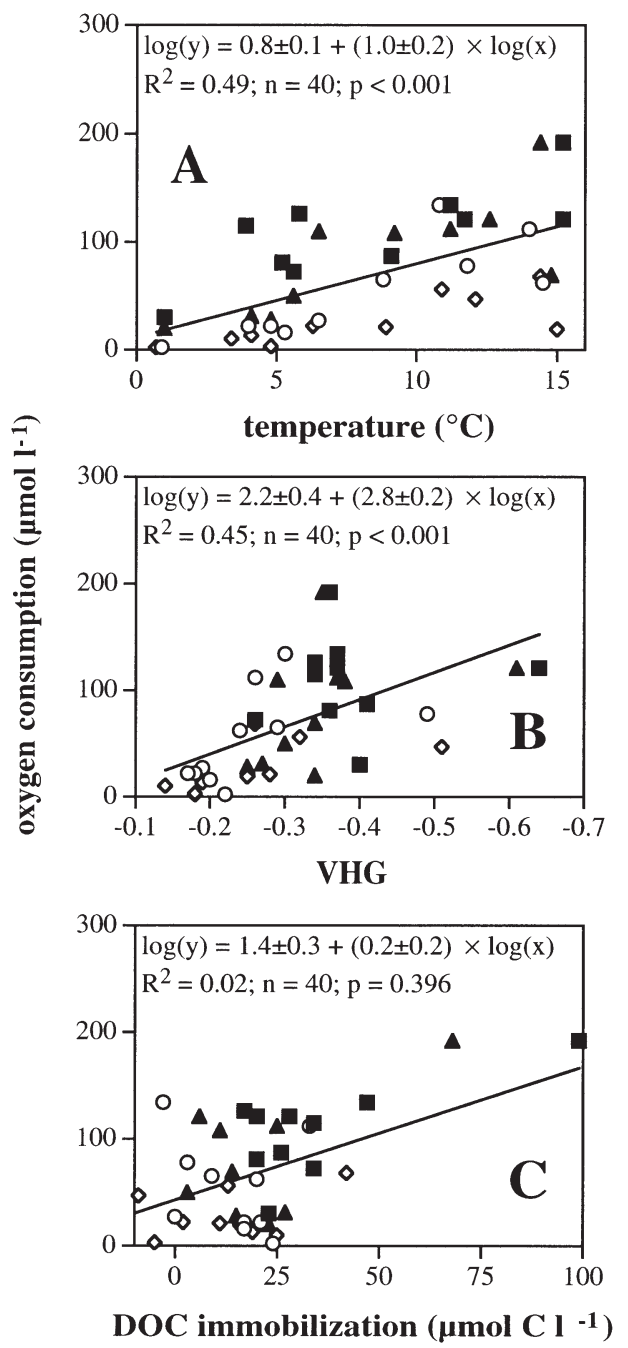

Fig. 5. Relation between apparent oxygen consumption during filtration through the riparian zone (within 0.9 to $1 \mathrm{~m}$ from the sediment-water interface) versus (A) temperature, (B) vertical hydraulic gradient (VHG), and (C) decrease in DOC concentration between river water and the subsurface sediment layer (DOC immobilization). Regression lines and equations refer to pooled data from all stations. Symbols represent

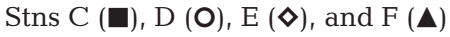

the clogging process than the stations with natural bed material (Fig. 2, Table 1).

The stations located within natural, undisturbed sediment showed higher abundance and production of porewater bacteria and a more pronounced decrease in oxygen concentration with distance from the watersediment interface than the stations with the artificially introduced gravel (Fig. 3, Table 2). However, there were also several distinct differences between Stns C and $F$, suggesting that organic matter transformation and microbial activity were not only determined by the physical structure of the filter material. The DOC retention efficiency (defined as the amount of DOC immobilized during filtration divided by the amount of DOC that infiltrated from the river surface) ranged from 12 to $20 \%$ at the stations on the riverbank, but ranged from 29 to $38 \%$ at Stn C located on the riverbed (Fig. 4, Table 2). Similarly, apparent oxygen consumption was significantly higher at Stn $\mathrm{C}$ than at all the other stations, especially during the cold season (Table 2). Although information on the hydrologic conditions at Stn $\mathrm{C}$ is limited, hydrodynamic modelling (using the 'modflow' transport model) provides evidence that the riverbed contributed only little $(<10 \%)$ to the transport of river water to the production well (Ingerle et al. 1999). If downstream subsurface flow prevailed over downwelling of river water into the sediment at Stn C, this would imply a higher HRT at this site and differences in the sources of organic matter between the riverbed and the sites located on the riverbank.

\section{Importance of DOC immobilization for the microbial metabolism in the hyporheic zone}

Removal of DOC from interstitial waters is often linked to the abundance and the activity of hyporheic bacteria (Findlay et al. 1993, Marmonier et al. 1995) and bacterial growth on porewater DOC has been demonstrated (Findlay et al. 1993, Mann \& Wetzel 1995). However, abiotic immobilization (via the diffusion of solutes into the biofilm matrix of sediments and adsorption onto biofilm binding sites and mineral surfaces) is considered to be an important mechanism in the removal of DOC from interstitial waters (McDowell 1985, Fiebig \& Lock 1991). Findlay \& Sobczak (1996) reported that DOC immobilization in bed-sediments of a nutrient-rich 3rd order stream (Wappinger Creek, USA) was only weakly correlated with temperature and oxygen consumption, but depended strongly on streamwater DOC concentration. In our study, the instantaneous bacterial utilization of the infiltrating DOC is only of minor importance for the removal of DOC as indicated by the weak correlation between DOC immobilization ( $\triangle \mathrm{DOC}$ ) and concurrent oxygen consumption (Table 4, Fig. 5C). In contrast to earlier reports (McDowell 1985, Findlay \& Sobczak 1996), however, there was no clear relationship detectable between $\triangle \mathrm{DOC}$ on the riverbank and the DOC concentration of the infiltrating river water (Table 4). We assume that adsorption processes were more pronounced on the riverbed than at the stations located on the riverbank. The higher DOC retention observed at Stn C compared to the other sampling sites (Fig. 4) may have been the result of abiotic immobilization processes rather than caused by spatial differences in microbial activity. 
Most of the DOC in natural waters is not readily available for bacteria (e.g. Thurman 1985). For the period of the investigation, 2 to $29 \%$ of the DOC found in the Enns River can be regarded as bioavailable DOC (Kolar et al. unpubl.). The measurements of Kolar et al. (unpubl.) may actually underestimate the bioavailability of the infiltrating DOC as scavenging of molecules within the sediment biofilm may allow the utilization of compounds that otherwise would not be accessible for bacterial degradation (Freeman \& Lock 1995, Findlay \& Sobczak 1996). However, even if we assume that the observed decline in DOC is exclusively attributable to microbial consumption, the observed losses of DOC were frequently lower than the apparent microbial respiration (in terms of carbon equivalents; Fig. 4). This discrepancy between the removal of DOC and oxygen from infiltrating river water was generally more pronounced at the stations with natural bed material than at those with artificially introduced gravel, but was observed at all sites from April to September 1998 (Fig. 4). During this period, DOC removal from porewater explained $36 \pm$ $25 \%$ (mean $\pm \mathrm{SD}$ ) of the variance in the apparent oxygen utilization. Our results are in good agreement with earlier observations, where the loss of DOC accounted for 24 to $39 \%$ of the concurrent oxygen depletion (Findlay et al. 1993).

The imbalance between $\triangle \mathrm{DOC}$ and HCR observed in our study (Fig. 4) strongly suggests that carbon sources other than infiltrating DOC contributed substantially to microbial demand. Recently, we proposed that POC may be the predominant carbon source for microbial metabolism because total bacterial biomass and production were highly correlated with the distribution of sediment-associated organic carbon (Brugger et al. in press).

\section{Factors determining the microbial oxygen consumption in the riparian zone}

Temperature is a major factor determining the metabolism of organic matter and biological activity in hyporheic habitats (e.g. Brunke \& Gonser 1997). Seasonal temperature variations have been demonstrated to influence the abundance and the production of bacteria in our system (Brugger et al. in press), and temperature alone explained $>70 \%$ of the seasonal variability in apparent oxygen consumption (Table 6). However, porewater temperature differed only slightly between the individual sampling sites at a given date (Fig. 2A) and is therefore not likely to be responsible for the observed spatial heterogeneity in the interstitial bacterial abundance, production, and oxygen consumption (Figs. 3 \& 4).
The residence time of the infiltrating water can also influence the interstitial oxygen consumption of the riparian zone. Findlay (1995) argued that the residence time of water in the hyporheic zone may explain the variability in oxygen distribution among streams, because the breakdown of interstitial organic matter depends largely on the duration of interaction between the organic material and the sediment biofilm. Based on the available filtration velocity data (Table 1), we calculated HCR rates (per infiltration area and unit time) for the investigated system. Because filtration velocity was averaged over the period of investigation in these calculations, these data represent only rough estimates of the hyporheic community respiration rates. HCR rates at Stn D ranged from $\sim 30 \mathrm{mmol} \mathrm{C}$ $\mathrm{m}^{-2} \mathrm{~d}^{-1}$ (during the cold season) to $\sim 110 \mathrm{mmol} \mathrm{C} \mathrm{m}^{-2} \mathrm{~d}^{-1}$ (during the warm season). In comparison, HCR rates of $\sim 30 \mathrm{mmol} \mathrm{C} \mathrm{m} \mathrm{m}^{-2}$ (cold season) and $\sim 60 \mathrm{mmol} \mathrm{C}$ $\mathrm{m}^{-2} \mathrm{~d}^{-1}$ (warm season) were obtained for Stn F. Therefore, once the longer residence time of the infiltrating water at Stn F was taken into account, community respiration was similar or even higher in the artificially introduced gravel compared to the original bank sediment. These results are consistent with the findings of Jones (1995) from bed-sediments of a small desert stream (Scyamore Creek, USA), where microbial oxygen consumption was inversely correlated with the sediment grain size. Calculated per sediment surface area, Jones (1995) found a more than 4-fold higher oxygen consumption rate for sediments with a mean particle diameter of $3.4 \mathrm{~mm}$ as compared to smaller sized $(0.5 \mathrm{~mm})$ sediments. The author explained the higher respiration in the coarser sediments by the higher interstitial flow rate and by potentially higher diffusive transport of oxygen within the sediment biofilm.

Overall, the apparent community respiration rates obtained in this study are within the range of published data. For example, Grimm \& Fischer (1984) reported a community respiration rate of $106 \mathrm{mmol} \mathrm{C}$ $\mathrm{m}^{-2} \mathrm{~d}^{-1}$ from shallow bed-sediments of Scyamore Creek and rates of $\sim 50 \mathrm{mmol} \mathrm{C} \mathrm{m}^{-2} \mathrm{~d}^{-1}$ were determined in surface sediments of a 3rd order mountain stream (Steina, Germany; Fischer et al. 1996, Pusch 1996).

\section{Role of bacteria for DOC immobilization and oxygen consumption in the riparian zone}

Porewater bacterial metabolism (Fig. 3D) accounted for less than $1 \%$ of the respiration-based community carbon consumption (assuming a bacterial growth efficiency of $10 \%$; cf. Mann \& Wetzel 1995). This is consistent with previous observations that porewater bacte- 
ria represented $<1 \%$ of the total bacteria present in the investigated system (Brugger et al. in press) and suggests that porewater bacteria do not play a significant role in the cycling of the interstitial organic carbon. We cannot directly compare the bacterial production rates obtained in this study with rates of sediment-associated bacterial production, because bacterial production in Brugger et al. (in press) was expressed on the basis of sediment dry mass and the conversion into area-based production rates would require assumptions regarding the specific weight of the undisturbed sediment. However, hyporheic community respiration at Stn F correlated well $(\mathrm{r}=0.682 ; \mathrm{n}=10 ; \mathrm{p}<0.05)$ with the sediment-associated bacterial production rates given in Brugger et al. (in press), supporting Pusch's (1996) argument that most of the oxygen removal in interstitial zones can be attributed to sedimentattached bacterial respiration.

Porewater bacterial abundance and production is not related to the distribution of DOC and oxygen within the riparian zone (Table 3). Thus, bacterial parameters were not included in models predicting DOC immobilization or oxygen consumption (Tables 5 \& 6). As indicated by the calculated area-based HCR rates, high bacterial abundance and production in the porewater of the shallow sediment layers of Stns $\mathrm{C}$ and $\mathrm{F}$ (Fig. 3C,D) do not necessarily reflect an overall higher bacterial activity in the original sediment compared to the artificially introduced gravel (Fig. 4). The accumulation of porewater bacteria near the sediment-water interface as well as the sharp decreases in bacterial abundance during the first meter of filtration (Fig. 3C) resulted probably from a combined effect of adsorption of bacteria and labile DOC onto the interstitial surfaces (e.g. Lawrence et al. 1995).

\section{Summary}

In the present paper we demonstrated that substantial amounts of oxygen were consumed in waters entering an experimental bank filtration site. Sediment-associated rather than interstitial bacteria were responsible for the observed decline in oxygen concentration via the utilization of POC and DOC. The activity of the free-living, interstitial microorganisms was highly temperature-dependent, but was not related to the amount of DOC immobilized during filtration. Furthermore, the immobilization of DOC from infiltrating water was significantly lower than the concurrent oxygen decline. The physical structure (i.e. the grain size distribution) of the riparian sediments controlled the flux of water and solutes into the riparian zone, and hence determined the relative importance of POC and DOC as carbon sources for the hyporheic organisms. Filtration velocity and hydraulic residence time of the infiltrating water were, however, not the major factors determining the area-based community respiration rate.

Acknowledgements. This work was part of a multidisciplinary program funded by Ennskraft Inc., Steyr (Austria). We thank the staff at Ennskraft, Dept. Technical Services, for help with sampling and for providing temperature and oxygen data. Hydraulic conductivity was determined by D. Sengschmitt (Inst. Hydraulics and Water Resources Management, Vienna Univ. of Technology). Special thanks go to N. Quéric for help in the lab and to H. L. Nemeschkal (Institute of Zoology, University of Vienna) for statistical advice. The comments of S. Findlay and 2 anonymous reviewers greatly improved the manuscript. This paper is part of the fulfillment of the requirements for a PhD degree from the University of Vienna for A.B.

\section{LITERATURE CITED}

Benner R, Strom M (1993) A critical evaluation of the analytical blank associated with DOC measurements by hightemperature catalytic oxidation. Mar Chem 41:153-160

Beyer W (1964) Zur Bestimmung der Wasserdurchlässigkeit von Kiesen and Sanden aus der Korngrössenverteilungskurve. Wasserwirtschaft-Wassertechnik 14:165-168

Bretschko G, Moser H (1993) Transport and retention of matter in riparian ecotones. Hydrobiologia 251:95-102

Brugger A, Reitner B, Kolar I, Quéric N, Herndl GJ (in press) Seasonal and spatial distribution of dissolved and particulate organic carbon and bacteria in the bank of an impounding reservoir on the Enns River, Austria. Freshw Biol

Brunke M, Gonser T (1997) The ecological significance of exchange processes between rivers and groundwater. Freshw Biol 37:1-33

Fiebig DM, Lock MA (1991) Immobilization of dissolved organic matter from groundwater discharging through the stream bed. Freshw Biol 26:45-55

Fiebig DM, Marxsen J (1992) Immobilization and mineralization of dissolved free amino acids by stream-bed biofilms. Freshw Biol 28:129-140

Findlay S (1995) Importance of surface-subsurface exchange in stream ecosystems: the hyporheic zone. Limnol Oceanogr 40:159-164

Findlay S, Sobczak WV (1996) Variability in removal of dissolved organic carbon in hyporheic sediments. J N Am Benthol Soc 15:35-41

Findlay S, Strayer D, Goumbala C, Gould K (1993) Metabolism of streamwater dissolved organic carbon in the shallow hyporheic zone. Limnol Oceanogr 38:1493-1499

Fischer H, Pusch M, Schwoerbel J (1996) Spatial distribution and respiration of bacteria in stream-bed sediments. Arch Hydrobiol 137:281-300

Ford TE, Naiman RJ (1989) Groundwater- surface water relationships in boreal forest watersheds: dissolved organic carbon and inorganic nutrient dynamics. Can J Fish Aquat Sci 46:41-49

Fraser BG, Williams DD (1998) Seasonal boundary dynamics of a groundwater/surface-water ecotone. Ecology 79: 2019-2031

Freedman DL, Smith CR, Noguera DR (1997) Dichloromethane biodegradation under nitrate-reducing conditions. Water Environ Res 69:115-125 
Freeman C, Lock MA (1995) The biofilm polysaccharide matrix: a buffer against changing organic substrate supply? Limnol Oceanogr 40:273-278

Freeman C, Chapman PJ, Gilman K, Lock MA, Reynolds B, Wheater HS (1995) Ion exchange mechanism and the entrapment of nutrients by river biofilms. Hydrobiologia 297:61-65

Grimm NB, Fischer SG (1984) Exchange between interstitial and surface water: implications for stream metabolism and nutrient cycling. Hydrobiologia 111:219-228

Hedin LO (1990) Factors controlling sediment community respiration in woodland stream ecosystems. Oikos 57:94-105

Hendricks SP (1993) Microbial ecology of the hyporheic zone: a perspective integrating hydrology and biology. J N Am Benthol Soc 12:70-78

Hendricks SP, White DS (1995) Seasonal biogeochemical patterns in surface water, subsurface hyporheic, and riparian groundwater in a temperate stream ecosystem. Arch Hydrobiol 134:459-490

Hoehn E, Zobrist J, Schwarzenbach RP (1983) Infiltration von Flusswasser ins Grundwasser-Hydrogeologische und hydrochemische Untersuchungen im Glattal. Gas-WasserAbwasser 63:401-410

Ingerle K, Herndl GJ, Schoeller F, Sommer R, Hasenleithner C (1999) Forschungsprojekt Uferfiltrat (Report). Schriftenreihe Forschung im Verbund, Vol 60, Verbund AG, Wien

Jones JB (1995) Factors controlling hyporheic respiration in a desert stream. Freshw Biol 34:91-99

Jones JB, Holmes RM (1996) Surface-subsurface interactions in stream ecosystems. TREE 11:239-242

Kaplan LA, Newbold JD (1993) Biogeochemistry of dissolved organic carbon entering streams. In: Ford TE (ed) Aquatic microbiology. An ecological approach. Blackwell Scientific Publications, Boston, p 139-166

Lawrence JR, Korber DR, Wolfaard GM, Caldwell DE (1995) Behavioural strategies of surface-colonizing bacteria. Adv Microbiol Ecol 14:1-75

Lee DR, Cherry JA (1987) A field exercise on groundwater flow using seepage meters and mini-piezometers. J Geol Education 27:6-10

Leichtfried M (1991) POM in bed sediments of a gravel stream (Ritrodat-Lunz study area, Austria). Verh Int Ver Limnol 24:1921-1925

Lock MA, Wallace RR, Costerton JW, Ventullo RM, Charlton SE (1984) River epilithion: toward a structural-functional model. Oikos 42:10-22

Lohr A (1969) Beitrag zur Ermittlung des kf-Wertes durch hydraulische Feldversuche. Gas- und Wasserfach 14: 369-376

Mann CJ, Wetzel RG (1995) Dissolved organic carbon and its

Editorial responsibility: Karel Šimek,

České Budějovice, Czech Republic utilization in a riverine wetland ecosystem. Biogeochemistry 31:99-120

Marmonier P, Fontvielle D, Gibert J, Vanek V (1995) Distribution of dissolved organic carbon and bacteria at the interface between the Rhone River and its alluvial interface. J N Am Benthol Soc 14:382-392

McDowell WD (1985) Kinetics and mechanism of dissolved organic carbon retention in a headwater stream. Biogeochemistry 1:329-352

Meyer JL (1994) The microbial loop in flowing waters. Microb Ecol 28:195-199

Naegeli MW, Uehlinger U (1997) Contribution of the hyporheic zone to ecosystem metabolism in a prealpine gravel-bed river. J N Am Benthol Soc 16:794-804

Porter KG, Feig YS (1980) The use of DAPI for identifying and counting aquatic microflora. Limnol Oceanogr 25:943-948

Pusch M (1996) The metabolism of organic matter in the hyporheic zone of a mountain stream, and its spatial distribution. Hydrobiologia 323:107-118

Pusch M, Fiebig D, Brettar I, Eisenmann H, Ellis BK, Kaplan LA, Lock MA, Naegeli MW, Traunspurger W (1998) The role of micro-organisms in the ecological connectivity of running waters. Freshw Biol 40:453-495

Romaní AM, Butturini A, Sabater F, Sabater S (1998) Heterotrophic metabolism in a forest stream sediment: surface versus subsurface zone. Aquat Microb Ecol 16:143-151

SAS Institute Inc. (1998) StatView 5.0 Reference Book

Schindler JE, Krabbenhoft DP (1998) The hyporheic zone as a source of dissolved organic carbon and carbon gases to a temperate forested stream. Biogeochemistry 43:157-174

Schwarzenbach RP, Giger W, Hoehn E, Schneider JK (1983) Behaviour of organic compounds during infiltration of river water to groundwater - field studies. Environ Sci Technol 17:472-479

Simon M, Azam F (1989) Protein content and protein synthesis rates of planktonic marine bacteria. Mar Ecol Prog Ser 51:201-213

Sobczak WV, Hedin LO, Klug MJ (1998) Relationships between bacterial productivity and organic carbon at a soil-stream interface. Hydrobiologia 386:45-53

Thurman EM (1985) Organic geochemistry of natural waters. Martinus Nijhoff/Dr W Junk Publishers, Dordrecht

Valett HM, Dahm CN, Campana ME, Morrice JA, Baker MA, Fellows CS (1997) Hydrologic influences on groundwatersurface water ecotones: heterogeneity in nutrient composition and retention. J N Am Benthol Soc 16:239-247

Vervier P, Dobson M, Pinay G (1993) Role of interaction zones between surface and ground waters in DOC transport and processing: consideration for river restoration. Freshw Biol $29: 275-284$

Submitted: November 20, 2000; Accepted: February 20, 2001 Proofs received from author(s): April 18, 2001 